\author{
A. V. Stadnichenko ${ }^{1}$, Yu. M. KRASNOPOLSKY ${ }^{2}$, T. G. YARNYKH ${ }^{1}$ \\ ${ }^{1}$ National University of Pharmacy \\ ${ }^{2}$ National Technical University "Kharkiv Polytechnic Institute"
}

\title{
EXPERIMENT PLANNING AT THE PHARMACEUTICAL DEVELOPMENT OF LIPOSOMAL CYTOSTATICS
}

At present, there is an increasing interest in developing new ways of drug delivery and targeted therapy, using nanotechnology and nanomaterials.

Aim - to study the order of carrying out of pharmaceutical development of liposoms with cytostatics. Propose the scope of the experiment to optimize the planned quality indicators and technological parameters.

Materials and methods. Analysis of normative documents, scientific literature and also the results of previous personal experimental studies, which became the basis for determining the methodology for the creation of liposomal drugs based on oxaliplatin and irinotecan. Lipids manufactured by Lipoid, Germany, were used to make liposomes. The lipid film was produced on a Buchi 210 rotary evaporator with a vacuum controller, at a residual pressure of $0.02 \mathrm{~atm}$. For homogenization, a high pressure extrusion method was used, which was carried out on a Microfluidiser M-110P (Microfluidics, USA).

Results and discussion. With the development of the pharmaceutical industry, there is a growing interest to the use of nanotechnology and nanomaterials. One of the practical implementation of nanotechnology is liposomes with cytostatics. Concentration of the active substance; $\mathrm{pH}$ and salt API; method of loading for API into liposomes; lipid to lipid ratio, lipids concentration; particle size and internal volume; lipid solubility in the step of lipid film preparation; stability testing of of finished products are factors that need to be studied and solved for the successful implementation of the development. Planning an experiment in the pharmaceutical development of liposomal oxaliplatin and liposomal irinotecan are complex studyes with using the principles of Quality by Design (QbD).

Conclusions. The requirements of normative documentation for creating liposomal forms of medicinal products are considered. At pharmaceutical development it is necessary to use the complex approach as the majority of the put questions can not be solved separately. An experiment planning system for the pharmaceutical development of liposomal preparations of irinotecan and oxaliplatin is proposed.

Key words: irinotecan; oxaliplatin; liposomes; a lipid bilayer; pharmaceutical development; chromatography; freeze drying

\section{О. В. Стадніченко, Ю. М. Краснопольський, Т. Г. Ярних Планування експерименту при фармацевтичній розробці ліпосомальних препаратів цитостатиків}

На теперішній час зростає інтерес до розробки нових засобів доставки ліків і до цільової терапії при використанні нанотехнологій і наноматеріалів.

Мета - вивчити порядок проведення фармацевтичної розробки ліпосомальних форм цитостатиків, запропонувати обсяг експерименту для оптимізації запланованих показників якості і технологічних параметрів.

Матеріали та методи. Аналіз нормативних документів, наукової літератури, а також результатів попередніх особистих експериментальних досліджень, які стали підгрунтям для визначення методології створення ліпосомальних препаратів на основі оксаліплатину та іринотекану. Для виготовлення ліпосом використовували ліпіди виробництва Lipoid, Німеччина. Ліпідну плівку отримували на роторному випарнику Buchi 210 з вакуумним контролером при залишковому тиску 0,02 атм. Для гомогенізації використовували метод екструзії при високому тиску на установці Microfluidiser M-110P (Microfluidics, США).

Результати та їх обговорення. 3 розвитком фармацевтичної науки зростає інтерес до використання нанотехнологій і наноматеріалів. Одним з перспективних напрямків $є$ ліпосоми з цитостатиками. Концентрація діючої речовини, $\mathrm{pH}$, метод завантаження активного компонента в ліпосоми; співвідношення компонентів і концентрація ліпідів у мембрані; розмір часток; розчинність ліпідів при виготовленні плівки; параметри гомогенізації; режим ліофілізації; стабільність після регідратації; дослідження стабільності готових лікарських форм впродовж терміну придатності - фактори, які необхідно вивчити для успішної реалізації розробки. Планування експерименту з фармацевтичної розробки ліпосомальних форм оксаліплатину та іринотекану є комплексним дослідженням з використанням принципів Quality by Design (QbD).

Висновки. Розглянуті вимоги нормативної документації для створення ліпосомальних форм лікарських препаратів. У фармацевтичній розробці необхідно використовувати комплексний підхід, оскільки більшість питань неможливо вирішити окремо. Запропоновано систему планування експерименту у фармацевтичній розробці ліпосомальних препаратів іринотекану і оксаліплатину.

Ключові слова: іринотекан; оксаліплатин; ліпосоми; ліпідний бішар; фармацевтична розробка; хроматографія; ліофілізація 


\section{А. В. Стадниченко, Ю. М. Краснопольский, Т. Г. Ярных Планирование эксперимента при фармацевтической разработке липосомальных препаратов цитостатиков}

В настоящее время возрастает интерес к разработке новых средств доставки лекарств и к целевой терапии при использовании нанотехнологий и наноматериалов.

Цель - изучить порядок проведения фармацевтической разработки липосомальных форм цитостатиков. Предложить объём эксперимента для оптимизации планируемых показателей качества и технологических параметров.

Материалы и методы. Анализ нормативных документов, научной литературы, а также результатов предыдущих собственных экспериментальных исследований, которые стали основой для определения методологии создания липосомальных препаратов на основе оксалиплатина и иринотекана. Для изготовления липосом использовали липиды производства Lipoid, Германия. Липидную плёнку получали на роторном испарителе Buchi 210 c вакуумным контроллером при остаточном давлении 0,02 атм. Для гомогенизации использовали метод экструзии при высоком давлении, которую проводили на установке Microfluidiser M-110P (Microfluidics, CША).

Результаты и их обсуждение. С развитием фармацевтической науки возрастает интерес к использованию нанотехнологий и наноматериалов. Одним из перспективных направлений являются липосомы с цитостатиками. Концентрация действующего вещества; $\mathrm{pH}$; метод загрузки активного компонента в липосомы; соотношение компонентов и концентрация липидов в мембране; размер частиц и внутренний объём; растворимость липидов при изготовлении плёнки; параметры гомогенизации; определение примесей в действующем веществе; режим лиофилизации; стабильность после регидратации; стабильность готовых лекарственных форм в течение срока годности - факторы, которые необходимо изучить для успешной реализации разработки. Планирование эксперимента по фармацевтической разработке липосомальных форм оксалиплатина и иринотекана является комплексным исследованием с применением принципов Quality by Design (QbD).

Выводы. Рассмотрены требования нормативной документации для создания липосомальных форм лекарственных препаратов. При фармацевтической разработке необходимо использовать комплексный подход, поскольку большинство поставленных вопросов невозможно решить по отдельности. Предложена система планирования эксперимента по фармацевтической разработке липосомальных препаратов иринотекана и оксалиплатина.

Ключевые слова: иринотекан; оксалиплатин; липосомы; липидный бислой; фармацевтическая разработка; хроматография; лиофилизация

\section{STATEMENT OF THE PROBLEM}

At present, there is an increasing interest in developing new ways of drug delivery and targeted therapy, using nanotechnology and nanomaterials. With the development of the pharmaceutical sector of nanoscale dosage forms and the shift from research to practical application, the research direction shifts from laboratory experiments to production standardization, development of regulatory requirements and the study of industrial approaches in the creation of complex structured drugs with particle sizes of 80-200 $\mathrm{nm}$ [1].

Along with the already existing pharmaceutical analysis methods, for description of medicinal facilities new physical and chemical methods and their modifications are used in a nanorange. In particular, it is possible to mark dynamic dispersion of light for determining size of particles, gel penetrating chromatography for determination of size of encapsulation of active pharmaceutical ingredients (APhI) in liposoms [2-4].

The critical stage of production of nanomedicines is a down-scaling of technological process. The scientific literature sanctified to creation of medicinal preparations of nanoscale distinguishes the row of parameters requiring the special attention at their production [5]: correlation of components; type of solvent; temperature of process; pressure; $\mathrm{pH}$ and row other.

\section{ANALYSIS OF RECENT RESEARCH AND PUBLICATIONS}

To the nanosize forms of medications, in particular liposoms, the different types of international normative documents, that regulate pharmaceutical development, production and control of medicinal facilities, are applicable.

Developers at planning of experiment must follow as by the base documents of International Council for Harmonisation of Technical Requirements for Pharmaceuticals for Human Use (ICH) for realization of pharmaceutical development $[6,7]$, so by the regulator documents of the separate states, touching medicinal nanosize forms directly, taking into account the specific of development of these materials $[8,9]$. These requirements determine the entire life cycle of the liposomal drug and include the requirements for the raw feed, its compatibility with the components of the preparation, analytical methods for studying the impurities of APhIs and lipid components, confirming the stability of the auxiliary membrane-forming lipid components, studying the sizes of the resulting nanoparticles, facilities. The technology of liposome formation and the methods of inclusion in the APhI nanoparticles require comprehensive study on the basis of an integrated experiment planning. Along with methods based on the use of ultrasonic treatment, injection, freezingthawing and others, preference is given to the method of 
homogenization at high pressure, which allows to standardize and scale the technological process [10].

\section{IDENTIFICATION OF ASPECTS OF THE PROBLEM UNSOLVED PREVIOUSLY}

The important is remained by the question of receipt of sterile preparation. An optimal method is steralizing filtration through the cascade of membranes. Thus most effective steralizing filtration is considered immediately in front of filling of the primary packing [11]. Wide distribution as facilities of oncotherapy was got by the liposom forms of cytostatics, that it is related to therapeutic advantage and unique properties of these nanoparticles [12,13]. Preparations of irinotecan and oxaliplatin are perspective therapeutic facilities during realization of different protocols of treatment of cancer diseases [14]. High antitumoral activity of irinotecan and oxaliplatin is accompanied by high toxicness, that does them the objects of researches at creation of the liposomes delivery systems.

\section{OBJECTIVE STATEMENT OF THE ARTICLE}

To study the order of the pharmaceutical development of liposomal forms of cytostatics. Suggest an experiment to optimize the volume of the planned indicators of quality and technological parameters.

\section{PRESENTATION OF THE MAIN MATERIAL OF THE RESEARCH}

When developing liposomal drugs, a number of questions are arise that require experimental studies aimed at determining: the content of $\mathrm{APhI}$ and the composition of the auxiliary components; the $\mathrm{pH}$ value and the presence of buffer components; method of loading APhI in liposomal nanoparticles; the ratio of membrane components and the concentration of lipids; particle size and internal volume of liposomes; the oxidation index; level of encapsulation; technological parameters of extrusion; type cryoprotectant and lyophilization mode. In addition, it is necessary to determine: the stability of phospholipids and APhIs; impurities of APhI and membrane-forming lipids, stability of liposomal emulsion after rehydration for the period of administration to the patient, stability of the finished dosage forms during the shelf life, etc.

At pharmaceutical development it is necessary to use the complex approach as the majority of the put questions can not be solved separately. So, the concentration of the active substance in the drug is determined by two factors - the minimum volume of the bottle for logistic and consumer convenience and the technological capabilities of capsulation. Thus, in the case of liposomes containing oxaliplatin and irinotecan, the concentration of the substance entering the lyophilization stage is $2 \mathrm{mg} / \mathrm{ml}$. At the same time, a maximum of capsulation is provided, which before lyophilization is: for irinotecan - not less than $90 \%$; for oxaliplatin - not less than $60 \%$. The proposed drugs are concentrates and before the therapeutic application they need a dilution determined by the conditions of therapy. The choice of buffer salts is determined from the study of the stability of APhI in salt solutions. In the case of oxaliplatin, the absence of salts in the finished liposomal drug is suggested. This is due to the presence of an atom of platinum, which is part of the molecule of oxaliplatin, which can easily participate in redox reactions and lead to the instability of the APhI and the formation of impurities. The $\mathrm{pH}$ value inside and outside the liposomes when working with irinotecan requires a variety of studies of the stability of the APhI. Given the potential for the use of the "chemical gradient" method, it is necessary to investigate the stability of API from $\mathrm{pH}$ values up 1.5-2.0 to 6.0. Low $\mathrm{pH}$ values characterize the states within the liposomes, at which the molecule is maximally protonated, and values close to neutral $\mathrm{pH}$ are characteristic for the protonated state of irinotecan and should lie in a range suitable for parenteral administration. High stability of $\mathrm{APhI}$ irinotecan in the $\mathrm{pH}$ range from 1.9 to 5.0 was noted. At the same time, the $\mathrm{pH}$ value of 5.5 was already unacceptable, due to the destruction of the active structure of the irinotecan molecule and the formation of impurities, the amount of which exceeded the specification.

The method of loading the APhI must take into account the chemical stability of molecules in the space of the design parameters of the technology. In the case of liposomes with oxaliplatin, given the lack of the properties of a weak amine, it is advisable to investigate the possibility of encapsulation by the passive capture method in the formation of liposomes from a lipid film and to investigate the chemisorption potential using negatively and positively charged lipids as lipid bilayer surface modifiers. The irinotecan molecule, which is an example of a weak amine, potentially has the ability to participate in encapsulation using the "chemical gradient" method. It is necessary to study the possibility of encapsulation with both a "pH gradient" and an "ammonium gradient". At the first stage, the experiments should include studies of the solubility of the lipids used in a suitable organic solvent. We have shown that the use of a "pH gradient", both from the point of view of the stability of the molecule and from the point of view of the achievable degree of encapsulation, is more preferable.

On the next stage realization of experiments is needed with the purpose of determination of optimal correlation of components of lipid membrane and concentration of lipids. The special attention it is necessary to spare to maintenance of cholesterol in the membrane of liposom. A cholesterol is a modifier, a step-up inflexibility of lipid membrane. However his surplus results in formation of particles, with a size more than $1000 \mathrm{HM}$, that results in impossibility of realization of steralizing filtration of liposom emulsion. It was shown by us, that maintenance of cholesterol in a lipid membrane over $20 \%$ mass, results in difficulties at reproducing of technological process.

One of the basic stages of receipt of liposom is homogenization. Working off the mode of homogenization be- 
gins on the stage of selection of composition and concentration of lipid membrane. Homogenization must provide the necessary range of sizes of liposoms emulsion, her stability in the flow of time and absence of large particles hampering steralizing filtration through membranes with the size of pores of $0.22 \mathrm{mcm}$. During realization of preliminary experiments optimal the method of homogenization was confessed at high pressure, with the obligatory cooling of emulsion during a technological process.

The size of particles must be controlled on every stage of technological process. At work of cerouss the size of liposoms must be forecast, on condition of stable indexes of technological process. We showed possibility of receipt of liposom the method of homogenization at pressures up to $1500 \mathrm{~atm}$.

To determine the internal volume of liposomes, it is necessary to carry out experiments based on the preparation of drugs with a marker substance, and further its removal by ultrafiltration. Determination of the substance of the marker in the ultrafiltrate will allow to determine two important technological factors - the internal volume of liposomes and the number of cycles of ultrafiltration necessary to create a "pH gradient".

Preservation of the basic material of liposomes - phospholipids is necessary for the stability of technological and therapeutic indices during the life cycle of the preparation. The study of stability should be carried out at the stages of developing the technology, using model samples and applying those parameters of the technological process that will be used in future to scale the process and obtain industrial samples of the preparation. We have shown that with the proposed process parameters, as in the case of liposomes with oxaliplatin, and in the case of liposomes with irinotecan, the oxidation index does not exceed 0.4.

Analytical support of pharmaceutical development is the use of HPLC - both in the reversed-phase version (for studying the composition of APhI impurities) and in the gel filtration variant (for analyzing the encapsulation of APhIs in liposomes).

The critical technological stage of production of liposomal forms of irinotecan and oxaliplatin is lyophilization. At working off this stage it is necessary to decide the row of scientific and technical questions, such as a type and concentration of cryoprotector used in liposome emulsion, mode of lyophilization, including the primary and secondary drying, with research minimum of possible temperature of the second stage and study of maintenance of remaining water in the prepared standards. Thereon the stage of experiment stability of the prepared preparations is investigated after регидратации, optimization of type and concentration of stabilizators.

The stability of the liposomal emulsion after rehydration for the period of administration to the patient is achieved by giving the liposomal emulsion the optimal value of the potential zeta, which will ensure the aggregate stability of the drug.

Separately from technological experiments researches of stability of the prepared medicinal form stand on the declared indexes of quality in a flow use-by of preparation date. At use-by of preparations date -1 must be studied 6 temporal points of storage of preparations in the regulated terms $(1,3,6,9,12$ and 15 months). The offered volume of experiments embraces all technological and control analytical area of creation of preparations, and allows complex to work out the problems of quality of preparation within the framework of conception of Quality by Design (QbD). This approach is most expedient in case of the difficult structured preparations, in particular liposom forms of cytostatics and allows to guarantee reproducing of technological and therapeutic descriptions of preparation on all stages of his production and therapeutic application.

\section{CONCLUSIONS}

1. The requirements of regulatory documentation for the creation of liposomal forms of drugs are considered. At pharmaceutical development it is necessary to use the complex approach as the majority of the put questions can not be solved separately.

2. A system for planning an experiment for the pharmaceutical development of liposomal preparations of irinotecan and oxaliplatin is proposed.

Conflict of Interests: authors have no conflict of interests to declare.

\section{REFERENCES}

1. Product quality for nanomaterials : current U. S. experience and perspective / K. M. Tyner, P. Zou, X. Yang et. al. // WIREs Nanomed Nanobiotechnol. - 2015. - Vol. 7, Issue 5. - P. 640-654. doi: 10.1002/wnan.1338

2. Nanoparticle characterization for cancer nanotechnology and other biological applications / S. C. Brown, M. Palazuelos, P. Sharma et al. // Methods Mol. Biol. - 2010. - P. 39-65. doi: 10.1007/978-1-60761-609-2_4

3. Characterization challenges for nanomaterials / D. R. Baer, J. E. Amonette, M. H. Engelhard et al. // Surf Interface Anal. - 2008. - Vol. 40. - P. 529-537.

4. Стадниченко, А. В. Разработка и валидация методики определения степени инкапсуляции иринотекана гидрохлорида в липосомы / А. В. Стадниченко, Ю. М. Краснопольский, В. И. Швец // Биофармац. журн. - 2015. - Т. 7, № 1. - С. 53-55.

5. Nanoparticles of biodegradable polymers for clinical administration of paclitaxel / S. S. Feng, L. Mu, K. Y. Win et al. // Curr. Med. Chem. - 2004. Vol. 11, Issue 4. - P. 413-424. doi: 10.2174/0929867043455909

6. Pharmaceutical development Q8(R2) // International Conference on Harmonisation of Technical Requirements for Registration of Pharmaceuticals for Human use. Version 4. - 2009. - 28 p. - Available at : https://www.ich.org/fileadmin/Public_Web_Site/ICH_Products/Guidelines/Quality/ Q8_R1/Step4/Q8_R2_Guideline.pdf

7. Development and Manufacture of Drug Substances Q11 // International Conference on Harmonisation of Technical Requirements for Registration of Pharmaceuticals for Human use. - 2012. - 36 p. - Available at : http://www.ich.org/fileadmin/Public_Web_Site/ICH_Products/Guidelines/ Quality/Q11/Q11_Step_4.pdf

8. Liposome Drug Products. Chemistry, Manufacturing, and Controls; Human Pharmacokinetics and Bioavailability ; and Labeling Documentation // Guidance for Industry. Food and Drug Administration. - 2015. - 17 p. 
9. Guideline for the Development of Liposome Drug Products.Ministry of Health, Labour and Welfare (MHLW). - Japan, 2016. - Available at : http:// www.nihs.go.jp/drug/section4/160328_MHLW_liposome_guideline.pdf

10. Toh, M. R. Liposomes as sterile preparations and limitations of sterilisation techniques in liposomal manufacturing / M. R. Toh, G. N. C. Chiu // Asian J. of Pharmac. Sci. - 2013. - Vol. 8, Issue 2. - P. 88-95. doi : 10.1016/j.ajps.2013.07.011

11. Yu, B. Microfluidic Methods for Production of Liposomes / B. Yu, R. J. Lee, L. J. Lee // Methods in Enzymol. - 2009. - P. 129-141. doi: 10.1016/ s0076-6879(09)65007-2

12. Huwyler, J. Tumor targeting using liposomal antineoplastic drugs / J. Huwyler, J. Drewe, S. Krahenbuhl // Int. J. Nanomed. - 2008. - Vol. 3. - P. 21-29.

13. Comparison of safety and toxicity of liposomal doxorubicin vs. conventional anthracyclines : a meta-analysis / S. M. Rafiyath, M. Rasul, B. Lee et al. // Experimental Hematol. \& Oncol. - 2012. - Vol. 1, Issue 1. - 10 p. doi: 10.1186/2162-3619-1-10

14. Capecitabine, oxaliplatin and irinotecan in combination, with bevacizumab (COI-B regimen) as first-line treatment of patients with advanced colorectal cancer. An Italian Trials of Medical Oncology phase II study / M. D. Bartolomeo, A. Ciarlo, A. Ciarlo et al. // Eur. J. of Cancer. - 2015. - Vol. 51, Issue 4. - P. 473-481. doi: 10.1016/j.ejca.2014.12.020

\section{REFERENCES}

1. Tyner, K. M., Zou, P., Yang, X., Zhang, H., Cruz, C. N., Lee, S. L. (2015). Product quality for nanomaterials: current U.S. experience and perspective. Wiley Interdisciplinary Reviews: Nanomedicine and Nanobiotechnology, 7 (5), 640-654. doi: 10.1002/wnan.1338

2. Brown, S. C., Palazuelos, M., Sharma, P., Powers, K. W., Roberts, S. M., Grobmyer, S. R., Moudgil, B. M. (2010). Nanoparticle Characterization for Cancer Nanotechnology and Other Biological Applications. Cancer Nanotechnology, 39-65. doi: 10.1007/978-1-60761-609-2_4

3. Baer, D. R., Amonette, J. E., Engelhard, M. H. et al. (2008). Characterization challenges for nanomaterials. Surf Interface Anal., 40, $529-537$.

4. Stadnychenko, A. V. Krasnopolskyiб Yu. M., Shvetc, V. I. (2015). Biofarmatcevticheskii zhurnal, 1 (7), 53-55.

5. Feng, S.-S., Mu, L., Win, K., Huang, G. (2004). Nanoparticles of Biodegradable Polymers for Clinical Administration of Paclitaxel. Current Medicinal Chemistry, 11 (4), 413-424. doi: 10.2174/0929867043455909

6. Pharmaceutical development Q8 (R2). (2009). International Conference on Harmonisation of Technical Requirements for Registration of Pharmaceuticals for Human use. (4), 28. Available at: https://www.ich.org/fileadmin/Public_Web_Site/ICH_Products/Guidelines/Quality/Q8_R1/Step4/ Q8_R2_Guideline.pdf

7. Development and Manufacture of Drug Substances Q11. (2012). International Conference on Harmonisation of Technical Requirements for Registration of Pharmaceuticals for Human use, 36. Available at: http://www.ich.org/fileadmin/Public_Web_Site/ICH_Products/Guidelines/Quality/Q11/Q11_Step_4.pdf

8. Liposome Drug Products. Chemistry, Manufacturing, and Controls; Human Pharmacokinetics and Bioavailability; and Labeling Documentation. (2015). Guidance for Industry. Food and Drug Administration, 17.

9. Guideline for the Development of Lposome Drug Products. (2016). Ministry of Health, Labour and Welfare (MHLW), Japan. Available at: http:// www.nihs.go.jp/drug/section4/160328_MHLW_liposome_guideline.pdf

10. Toh, M.-R., Chiu, G. N. C. (2013). Liposomes as sterile preparations and limitations of sterilisation techniques in liposomal manufacturing. Asian Journal of Pharmaceutical Sciences, 8 (2), 88-95. doi: 10.1016/j.ajps.2013.07.011

11. Yu, B., Lee, R. J., Lee, L. J. (2009). Microfluidic Methods for Production of Liposomes. Methods in Enzymology, 129-141. doi: 10.1016/s00766879(09)65007-2

12. Huwyler, J., Drewe, J., Krahenbuhl, S. (2008). Tumor targeting using liposomal antineoplastic drugs. Int J Nanomedicine, 3, 21-29.

13. Rafiyath, S. M., Rasul, M., Lee, B., Wei, G., Lamba, G., Liu, D. (2012). Comparison of safety and toxicity of liposomal doxorubicin vs. conventional anthracyclines: a meta-analysis. Experimental Hematology \& Oncology, 1 (1), 10. doi: 10.1186/2162-3619-1-10

14. Di Bartolomeo, M., Ciarlo, A., Bertolini, A., Barni, S., Verusio, C., Aitini, E., Bajetta, E. (2015). Capecitabine, oxaliplatin and irinotecan in combination, with bevacizumab (COI-B regimen) as first-line treatment of patients with advanced colorectal cancer. An Italian Trials of Medical Oncology phase II study. European Journal of Cancer, 51 (4), 473-481. doi: 10.1016/j.ejca.2014.12.020

\section{Information about authors:}

Stadnychenko A. V., Ph. D. of Pharmaceutical Sciences, department technology of drugs, National University of Pharmacy. E-mail: alstn@mail.ru. ORCID - http://orcid.org/0000-0003-3450-3899

Krasnopolskiy Yu. M., Doctor of Pharmaceutical Sciences, Professor, National Technical University “Kharkiv Polytechnic Institute”.

E-mail: biotech_ntu_khpi@ukr.net. ORCID - http://orcid.org/0000-0003-3469-5827

Yarnykh T. G., Doctor of Pharmacy, Professor, Head of drugs technology department., National University of Pharmacy. E-mail: tl.@nuph.edu.ua. ORCID - http://orcid.org/0000-0001-8496-1578

Відомості про авторів:

Стадніченко О. В., канд. фарм. наук, здобувач кафедри технології ліків, Національний фармацевтичний університет. E-mail: alstn@mail.ru. ORCID - http://orcid.org/0000-0003-3450-3899

Краснопольський Ю. М., д-р фарм. наук, професор, Національний технічний університет «Харківський політехнічний інститут».

E-mail: biotech_ntu_khpi@ukr.net. ORCID - http://orcid.org/0000-0003-3469-5827

Ярних Т. Г., д-р фарм. наук, професор, завідувач кафедри технології ліків, Національний фармацевтичний університет

E-mail: tl.@nuph.edu.ua. ORCID - http://orcid.org/0000-0001-8496-1578

Сведения об авторах:

Стадниченко А. В., канд. фарм. наук, соискатель кафедры технологии лекарств, Национальный фармацевтический университет.

E-mail: alstn@mail.ru. ORCID - http://orcid.org/0000-0003-3450-3899

Краснопольский Ю. М., д-р фарм. наук, профессор, Национальный технический университет «Харьковский политехнический институт».

E-mail: biotech_ntu_khpi@ukr.net. ORCID - http://orcid.org/0000-0003-3469-5827

Ярных Т. Г., д-р фарм. наук, профессор, заведующая кафедрой технологии лекарств, Национальный фармацевтический университет.

E-mail: tl.@nuph.edu.ua. ORCID - http://orcid.org/0000-0001-8496-1578

Рекомендована д. фарм. н., професором О. А. Рубан Надійшла до редакції 20.11.2017 p. 